\title{
Lebanon: Report on Performance Under the Program Supported by Emergency Post-Conflict Assistance
}

This report on Lebanon's performance under the program supported by emergency post-conflict assistance was circulated to the Executive Directors of the IMF for their information. It was prepared by a staff team of the International Monetary Fund and is based on the information available at the time it was issued on November 28, 2007. The views expressed in this document are those of the staff team and do not necessarily reflect the views of the government of Lebanon or the Executive Board of the IMF.

The policy of publication of staff reports and other documents by the IMF allows for the deletion of market-sensitive information.

To assist the IMF in evaluating the publication policy, reader comments are invited and may be sent by e-mail to publicationpolicy@imf.org

Copies of this report are available to the public from International Monetary Fund $\bullet$ Publication Services

700 19th Street, N.W. • Washington, D.C. 20431

Telephone: (202) 6237430 • Telefax: (202) 6237201

E-mail: publications@imf.org • Internet: http://www.imf.org

Price: $\$ 18.00$ a copy

\section{International Monetary Fund} Washington, D.C. 



\title{
INTERNATIONAL MONETARY FUND
}

\author{
LEBANON \\ Report on Performance Under the Program Supported by \\ Emergency Post-Conflict Assistance \\ Prepared by the Middle East and Central Asia Department \\ (In consultation with other departments) \\ Approved by Lorenzo Pérez and Scott Brown
}

November 28, 2007

- The Executive Board approved Emergency Post-Conflict Assistance (EPCA) for 25 percent of quota, or SDR 50.75 million, in April 2007, and Lebanon drew the full amount shortly thereafter. The EPCA-supported program for 2007 is based on the five-year reform program presented by the authorities at the Paris III conference in January 2007. This report updates Executive Directors on performance under the program relative to the end-September 2007 indicative targets and monitorable actions. A safeguards assessment of the Banque du Liban (BdL) is underway.

- The staff's findings are based on discussions held in Beirut November 1-9, 2007. The mission comprised Messrs. Gardner (head), Schimmelpfennig, Sdralevich, and Sosa (all MCD); and Messrs. Finger (PDR) and Mati (FAD). The mission met with the governor of the central bank, the minister of finance, the minister of economy and trade, and senior government officials.

- This report focuses on developments through September and prospects for the remainder of the 2007 program supported by EPCA. Although the government prepared a draft 2008 budget, key policy measures still need to be identified and the outlook is also dependent on the pace at which the legislative backlog can be absorbed. Staff will update the 2008 projections once the new government announces its policy agenda.

- The 2007 program is broadly on track. Despite a very difficult political environment, all end-September targets were met, except for the monitorable action on raising gasoline excises. Fiscal revenues were stronger than expected, and net debt was contained below the program ceiling. Owing to strong deposit inflows, the central bank accumulated international reserves at a faster pace than targeted, and government net borrowing from the BdL was limited as envisaged, despite shortfalls in expected donor support. The endDecember monitorable action on inviting expressions of interest to participate in the privatization of two mobile phone networks was effectively met in November. 
I. Background and Recent Developments ....................................................................

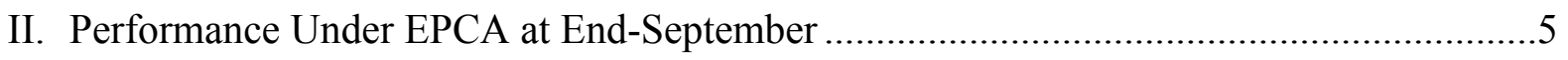

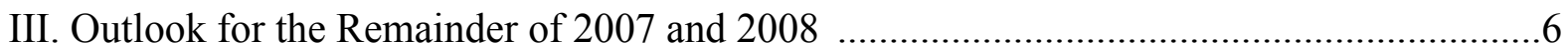

Figure

1. Recent Developments, January 2005-November 2007 ..............................................4

\section{Text Table}

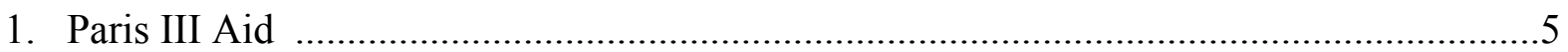

\section{Tables}

1. Selected Economic Indicators, 2003-07.............................................................

2. Quantitative Indicative Targets Under the Program Supported by Emergency Post-Conflict Assistance, March-December 2007 .......................................................

3. Monitorable Actions for the Period March-December 2007 ..........................................10 


\section{BACKGROUND AND RECENT DEVELOPMENTS}

1. The parliamentary majority and the opposition were not able to reach a compromise on a successor to President Lahoud, whose term came to an end on November 23. Constitutionally, the prime minister takes on the presidential responsibilities during this vacuum. Prime Minister Siniora has indicated that, until a new president is elected, his government would be acting in a caretaking role and refrain from taking new political initiatives. The ruling coalition and the opposition are engaged in discussions over the election of a new president who would then appoint a new prime minister and cabinet.

2. Notwithstanding political tensions and repeated security incidents, the economic recovery from the 2006 post-conflict trough has maintained momentum. Developments through July suggest that real GDP could grow by 2-3 percent in 2007 (Figure 1 and Table 1). Exports and imports have been buoyant in the first seven months of 2007, and it is expected that the trade and the current account deficits will widen relative to 2006. With rising international commodity prices and the depreciation of the U.S. dollar against the euro, CPI inflation has risen in the third quarter of 2007, and is projected to reach 5 percent in December 2007 (year-on-year). Inflows of external donor support of the government have continued to fall short of expectations, partly because negotiations have taken longer than envisaged; Paris III disbursements of budgetary grants and loans for 2007 are now projected at $\$ 0.8$ billion compared with $\$ 2.0$ billion assumed under EPCA (Text Table 1). Most of this inflow is expected to come in at the end of the year.

\section{Financial markets have weathered the political impasse and global financial} market turbulence quite well. Partly in response to the global repricing of risks, spreads increased over the summer. However, the Eurobond market saw very limited trading, suggesting that investors are generally maintaining their positions pending a resolution of the political situation. Deposit inflows have continued at a sustained pace, with broad money growing at an annual rate of 11 percent. However, deposit dollarization has edged up slowly to over 76 percent. There has been little market reaction to the failure to elect a president by the November 23 deadline, as concerns that the outgoing president would name a second and parallel governments did not materialize. 
Figure 1. Lebanon: Recent Developments, January 2005-November 2007

Activity is recovering slowly, despite political tensions and security incidents

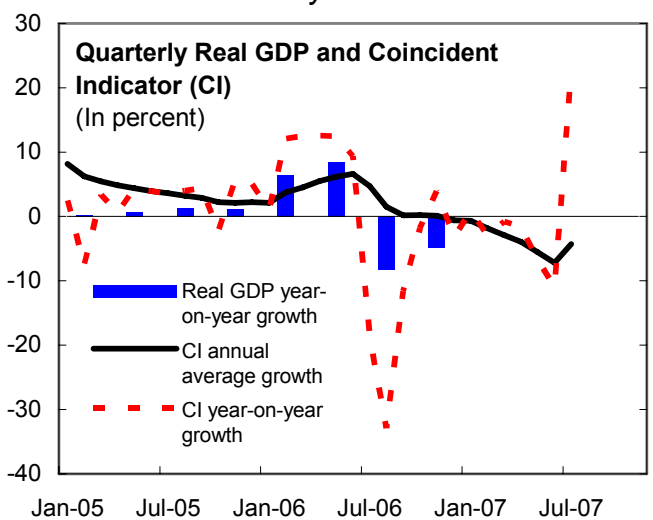

Exports and imports are recovering

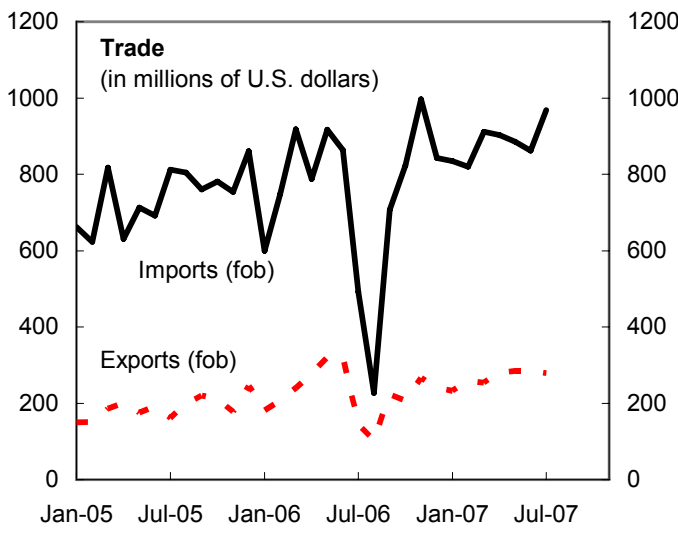

Reserves build-up has continued because of sustained deposit inflows

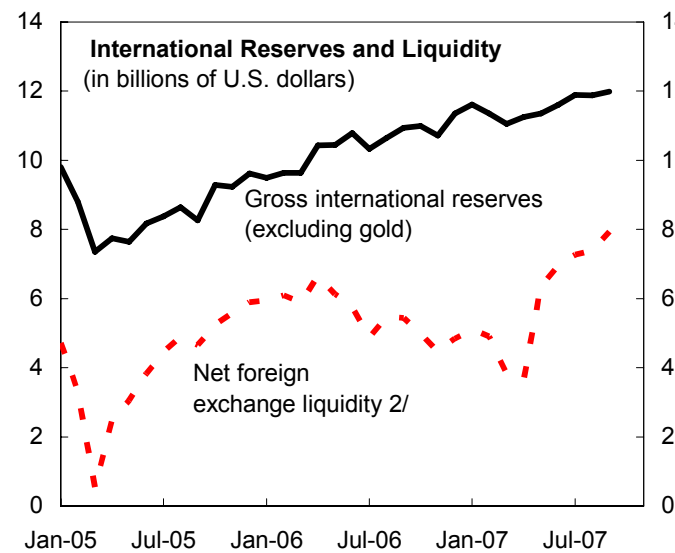

Inflation is picking up again, largely reflecting international developments

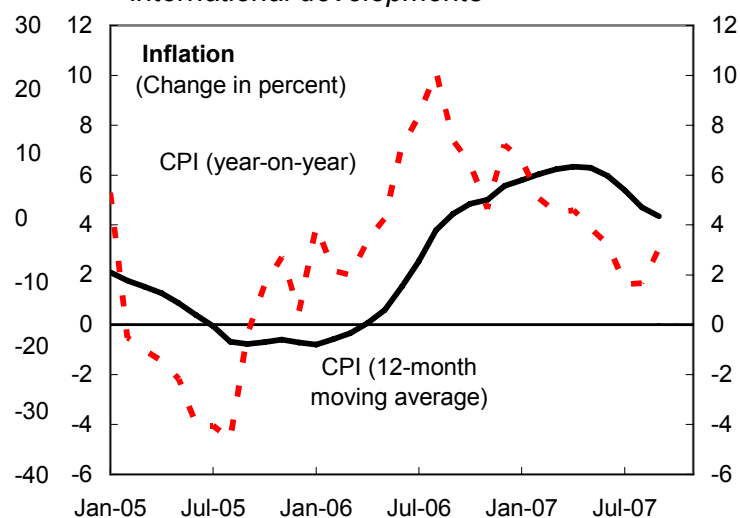

Deposit growth has been strong despite the political stalemate

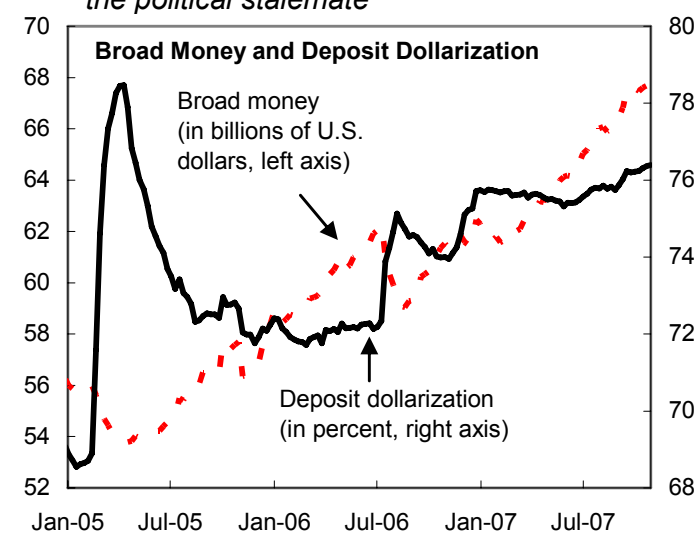

Spreads have widened broadly in line with global market developments

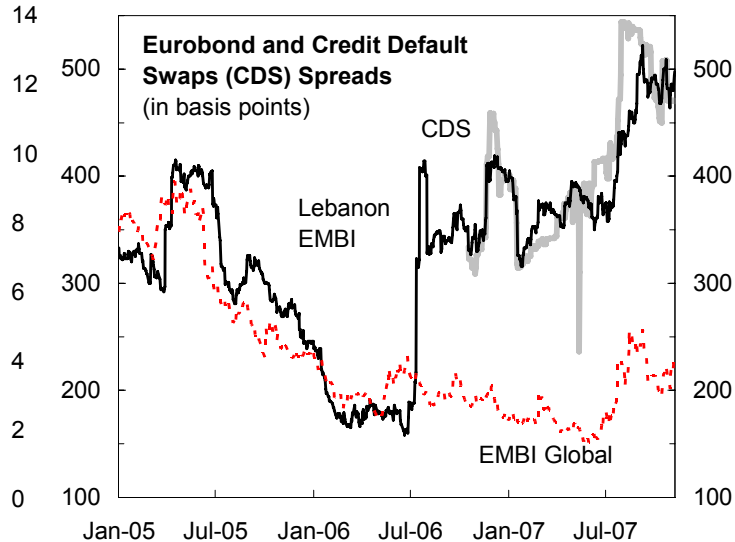

Sources: Lebanese authorities; J.P. Morgan; Bloomberg; and Fund staff calculations.

$1 /$ Coincident indicator is a composite indicator of economic activity monitored by the central bank.

2/ Defined as gross international reserves minus principal and interest due over the next 12 months on all foreign currency liabilities of the central bank to entities other than the government of Lebanon. Excludes long-term foreign exchange liabilities of the central bank. 
Text Table 1. Lebanon: Paris III Aid

(In millions of U.S. dollars, unless otherwise specified)

\begin{tabular}{|c|c|c|c|c|c|c|c|}
\hline & \multirow{3}{*}{$\begin{array}{l}\text { Total } \\
\text { Pledges }\end{array}$} & \multicolumn{6}{|c|}{ New Grants and Loans to Government } \\
\hline & & \multicolumn{2}{|c|}{ Paris III Pledges } & \multicolumn{2}{|c|}{ Rev. Proj. for 2007-10 1/ } & \multicolumn{2}{|c|}{2007} \\
\hline & & Total & $\begin{array}{l}\text { Of Which: } \\
\text { Budget } \\
\text { Support }\end{array}$ & $\begin{array}{l}\text { Budget } \\
\text { Support 2/ }\end{array}$ & $\begin{array}{c}\text { Grant } \\
\text { Element 3/ } \\
\text { (Estimate, in } \\
\text { percent) }\end{array}$ & Proj. & $\begin{array}{l}\text { Received } \\
\text { Jan-Sept }\end{array}$ \\
\hline Total & 7,565 & 5,018 & 2,327 & 2,716 & 47.5 & 793 & 200 \\
\hline Multilateral & 3,978 & 2,213 & 835 & 667 & 43.1 & 174 & 100 \\
\hline Bilateral & 3,587 & 2,805 & 1,492 & 2,048 & 48.9 & 619 & 100 \\
\hline
\end{tabular}

Sources: Lebanese authorities, and Fund staff estimates.

$1 /$ The financial terms of some loans are still uncertain.

2/ Outright budget support plus project loans and grants that support the existing expenditure envelope.

3/ Based on a discount rate of 7.45 percent, Lebanon's average projected rate for U.S. dollar market financing.

\section{Performance Under EPCA AT End-SePtember}

\section{The primary balance and net debt targets for end-September 2007 were met} with significant margins (Table 2). The primary balance (cash basis, excluding grants as defined in the program) posted a small surplus of 0.3 percent of GDP, compared with a projected deficit of 2.8 percent of GDP. This substantial overperformance results from better than projected revenue collection (Value-Added Tax and telecom revenues in particular show a stronger trend than expected) and delays in the execution of capital expenditure as well as lower than expected transfers to the power utility, reflecting in part electricity rationing through power cuts. As a result, net debt was contained to below the target despite somewhat higher than projected interest payments. At the same time, it should be noted that the budgetary cost of higher fuel prices will be felt only in 2008 as much of the fuel supplies for Electricité du Liban are financed through letters of credit.

\section{The program targets on international reserves and government net borrowing} from the BdL were also met comfortably. Given the continued deposit inflows, and in the absence of foreign exchange market pressures, the BdL was able to increase its gross international reserves (excluding gold) by $\$ 400$ million during the third quarter to $\$ 12$ billion by end-September 2007, somewhat higher than expected, and despite significant shortfalls in donor support relative to program expectations. ${ }^{1}$ Despite the ample liquidity in the system,

\footnotetext{
${ }^{1}$ In the program definition, reserves (including gold and Lebanese Eurobonds) increased to $\$ 17.8$ billion. For program purposes, however, the floor on international reserves is adjusted for changes in the Eurobond portfolio
} 
commercial banks were reluctant to roll over government paper at t-bill offer rates which have remained unchanged since early 2005 , and the government had to rely on financing from the BdL again during the third quarter, though still below the end-September ceiling.

6. The government did not introduce a floor (of $\$ \mathbf{\$ 0 . 2 0}$ per liter) on gasoline excises by end-September as previously envisaged (Table 3). The increase in international oil prices since May 2007 has been absorbed largely by lowering gasoline excises, which are thus yielding minimal revenue at current oil prices. As such, the planned introduction of a floor on gasoline excises would have required an increase in the retail price of around 30 percent. The authorities did not consider this to be feasible in the current very difficult political circumstances and were also concerned about the possible inflationary impact. However, they did raise retail prices by $2 \frac{1}{2}$ to 3 percent in November to prevent the excises from becoming negative. In 2007, the overperformance on other revenue sources is expected to more than offset the resulting shortfall from excises (around $1 / 2$ percent of GDP in the last quarter). However, raising gasoline excises remains an important pillar of the Paris III fiscal adjustment objectives.

7. Progress has also been made on structural reforms. The global income tax law was approved by Cabinet in November. The law significantly improves the tax system, though it leaves important details to be specified by ministerial decrees. Introduction of the global income tax will likely be delayed to 2009- one year later than planned under Paris III-given the technical work still needed on the related administrative measures. On the expenditure side, the new cash management unit is in the process of designing a cash flow plan, while work on multiyear budgeting in pilot ministries is continuing. With respect to the power sector reforms, the authorities expect to switch some production from fuel oil to gas by mid-2008 which should lower production costs significantly. However, the installation of remote meters to improve billing, and thus its budgetary cost, are likely to be delayed into 2008.

\section{OUTLOOK FOR THE REMAINDER OF 2007 AND 2008}

8. Given the strong performance through September, fiscal targets for 2007 appear achievable with an ample margin. The authorities expect revenue overperformance through the first three quarters of the year to compensate for the shortfall in excises. In addition, spending is likely to be lower than projected under the program, as the authorities now expect lower transfer payments and low execution of foreign financed capital expenditures. In all, the authorities expect significant overperformance on the primary fiscal balance (excluding grants). This should more than offset the somewhat higher interest spending

(See the Technical Memorandum of Understanding attached to the EPCA Letter of Intent, IMF Staff Country Report No. 07/177). 
relative to that projected under EPCA, so that government net debt would also come out below the program ceiling, adjusted for the significant shortfall in budget grants.

9. The target on international reserves is also achievable. Provided the political situation remains manageable, financial inflows are expected to continue at a sustained pace through the remainder of the year, which should allow the BdL to maintain international reserves at their current level or realize a modest further build-up.

10. The challenge in the fourth quarter is to reduce government net borrowing from the BdL as envisaged under the program. In this regard, the exchange of LL 1 trillion (\$667 million) in certificates of deposits for treasury bills effected in October was an important step to reduce the government's reliance on BdL financing in as much as it facilitated the government's ability to tap the market, by raising implicit yields well above the t-bill offer rate The authorities commitment to the end-year financing target will require deliberate efforts to mobilize additional market financing.

\section{The privatization process of the two mobile phone networks has been initiated} ahead of schedule. On November 2, the government issued a request for applications to participate in the auction for two thirds of the two existing mobile phone licenses, assets, and contracts, thus effectively meeting the end-December monitorable action under EPCA. The auction is scheduled for the first quarter of 2008, and the transfer of ownership is expected to be completed during 2008. The remaining one third will be sold on the stock exchange through an initial public offering.

\section{The authorities restated their commitment to the 2008 objectives outlined in the} Article IV staff report, and the mission did not discuss an updated 2008 projection with the authorities. At this stage, policy plans are still too uncertain in regard to key revenue and expenditure issues to provide the basis for a solid projection. Although the outgoing government has adopted a draft 2008 budget, the issue of how to compensate for the loss of fuel excise revenue is still open, and the draft budget does not provide enough guidance on the timing and cost of energy sector reform, or the policies underlying assumed reductions in transfers. Details on fiscal policy plans for 2008 will need to be discussed with the next government. 
Table 1. Lebanon: Selected Economic Indicators, 2003-07

\begin{tabular}{|c|c|c|c|c|c|c|}
\hline & \multirow[b]{2}{*}{$\begin{array}{c}2003 \\
\text { Act. }\end{array}$} & \multirow[b]{2}{*}{$\begin{array}{c}2004 \\
\text { Act. }\end{array}$} & \multirow[b]{2}{*}{$\begin{array}{l}2005 \\
\text { Act. }\end{array}$} & \multirow[b]{2}{*}{$\begin{array}{c}2006 \\
\text { Prel. Act. }\end{array}$} & \multicolumn{2}{|c|}{2007} \\
\hline & & & & & $\begin{array}{c}\text { IMF Staff } \\
\text { Country Report } \\
\text { No. 07/177 }\end{array}$ & Proj. \\
\hline Output and prices & \multicolumn{6}{|c|}{ (Annual percentage change) } \\
\hline Real GDP (market price) & 4.1 & 7.5 & 1.1 & 0.0 & 1.0 & 2.0 \\
\hline GDP deflator & 1.6 & 0.9 & -0.6 & 5.6 & $\ldots$ & 3.0 \\
\hline Consumer prices (end-of- period) & 2.2 & 2.0 & 0.5 & 7.2 & 2.0 & 5.0 \\
\hline Consumer prices (period average) & 1.3 & 1.7 & -0.7 & 5.6 & 3.5 & 4.0 \\
\hline Investment and saving & \multicolumn{6}{|c|}{ (In percent of GDP) } \\
\hline Gross capital formation & 19.3 & 22.0 & 16.9 & 11.6 & 16.6 & 16.7 \\
\hline Government & 3.1 & 3.3 & 2.2 & 2.5 & 5.0 & 2.8 \\
\hline Nongovernment & 16.2 & 18.8 & 14.8 & 9.1 & 11.7 & 13.9 \\
\hline Gross national savings & 6.1 & 6.5 & 3.4 & 5.6 & 5.6 & 6.3 \\
\hline Government & -10.2 & -5.4 & -6.2 & -8.6 & -7.4 & -9.3 \\
\hline Nongovernment & 16.3 & 11.9 & 9.6 & 14.2 & 13.1 & 15.6 \\
\hline Public finances & \multicolumn{6}{|c|}{ (In percent of GDP) } \\
\hline Revenue (including grants) & 22.1 & 23.1 & 22.8 & 24.7 & 26.7 & 25.1 \\
\hline Expenditure (including unidentified measures in 2008) & 35.4 & 31.8 & 31.2 & 35.8 & 39.1 & 37.1 \\
\hline Budget balance (including grants) & -13.3 & -8.6 & -8.4 & -11.1 & -12.4 & -12.0 \\
\hline Primary balance (including grants) & 3.3 & 3.5 & 2.1 & 1.7 & 0.0 & 0.8 \\
\hline Primary balance (excluding grants) & 3.3 & 3.5 & 2.1 & -1.2 & -3.7 & -0.9 \\
\hline Total government debt & 169 & 167 & 178 & 177 & 176 & 173 \\
\hline Monetary sector & \multicolumn{6}{|c|}{ (Annual percentage change, unless otherwise indicated) } \\
\hline Credit to the private sector & 0.3 & 5.2 & 1.9 & 6.0 & 5.0 & 2.2 \\
\hline Base money & 12.3 & 10.3 & 4.7 & 8.2 & 4.4 & 12.6 \\
\hline Broad money $1 /$ & 15.5 & 12.3 & 3.5 & 6.4 & 3.5 & 11.0 \\
\hline Velocity of broad money (level) & 0.4 & 0.4 & 0.4 & 0.4 & 0.4 & 0.4 \\
\hline Interest rates (period average, in percent) & & & & & & \\
\hline Three-month treasury bill rate & 6.7 & 5.2 & 5.2 & 5.2 & $\ldots$ & $\ldots$ \\
\hline Two-year treasury bill rate & 8.0 & 7.9 & 8.5 & 8.7 & 8.2 & 8.7 \\
\hline External sector & \multicolumn{6}{|c|}{ (In percent of GDP, unless otherwise indicated) } \\
\hline Exports of goods (in US\$, percentage change) & 43.2 & 18.3 & 11.1 & 22.5 & 12.9 & 19.2 \\
\hline Imports of goods (in US\$, percentage change) & 10.4 & 30.3 & -1.2 & 1.8 & 17.5 & 19.0 \\
\hline Merchandise trade balance & -24.2 & -30.1 & -28.4 & -25.3 & -29.2 & -28.6 \\
\hline Current account excluding official transfers & -13.9 & -16.0 & -14.2 & -7.2 & -15.3 & -11.5 \\
\hline Current account including official transfers & -13.2 & -15.5 & -13.6 & -6.0 & -11.0 & -10.4 \\
\hline Foreign direct investment & 8.7 & 10.9 & 12.2 & 12.0 & 7.6 & 8.7 \\
\hline Total external debt & 175 & 187 & 190 & 197 & 183 & 209 \\
\hline Gross reserves (in millions of U.S. dollars) & 10,271 & 9,575 & 9,611 & 11,353 & 10,440 & 12,089 \\
\hline In months of next year imports of goods and services & 8.1 & 7.7 & 7.2 & 7.5 & 6.7 & 7.3 \\
\hline In percent of short-term external debt $2 /$ & 35.6 & 27.1 & 28.4 & 32.2 & 32.5 & 30.6 \\
\hline In percent of banking system foreign currency deposits & 40.3 & 31.9 & 29.0 & 30.1 & 26.7 & 28.4 \\
\hline In percent of total banking system deposits & 24.8 & 21.0 & 20.1 & 21.9 & 19.3 & 20.7 \\
\hline \multicolumn{7}{|l|}{ Memorandum items: } \\
\hline Nominal GDP (in billions of U.S. dollars) & 19.8 & 21.5 & 21.6 & 22.8 & 23.6 & 23.9 \\
\hline Net imports of petroleum products (in millions of U.S. dollars) & $-1,057$ & $-1,833$ & $-2,082$ & $-2,172$ & $-2,072$ & $-2,361$ \\
\hline Local currency per U.S. dollar (period average) & 1,508 & 1,508 & 1,508 & 1,508 & $\ldots$ & $\ldots$ \\
\hline Real effective exchange rate (annual average, percent chang & -10.7 & -6.8 & -4.1 & 2.2 & $\ldots$ & $\ldots$ \\
\hline Stock market index & 457 & 637 & 1,309 & 1,184 & $\ldots$ & $\ldots$ \\
\hline
\end{tabular}

Sources: Lebanese authorities; and Fund staff estimates.

$1 /$ Defined as cash in circulation plus resident and non-resident deposits.

2/ Short-term debt on a remaining maturity basis. 


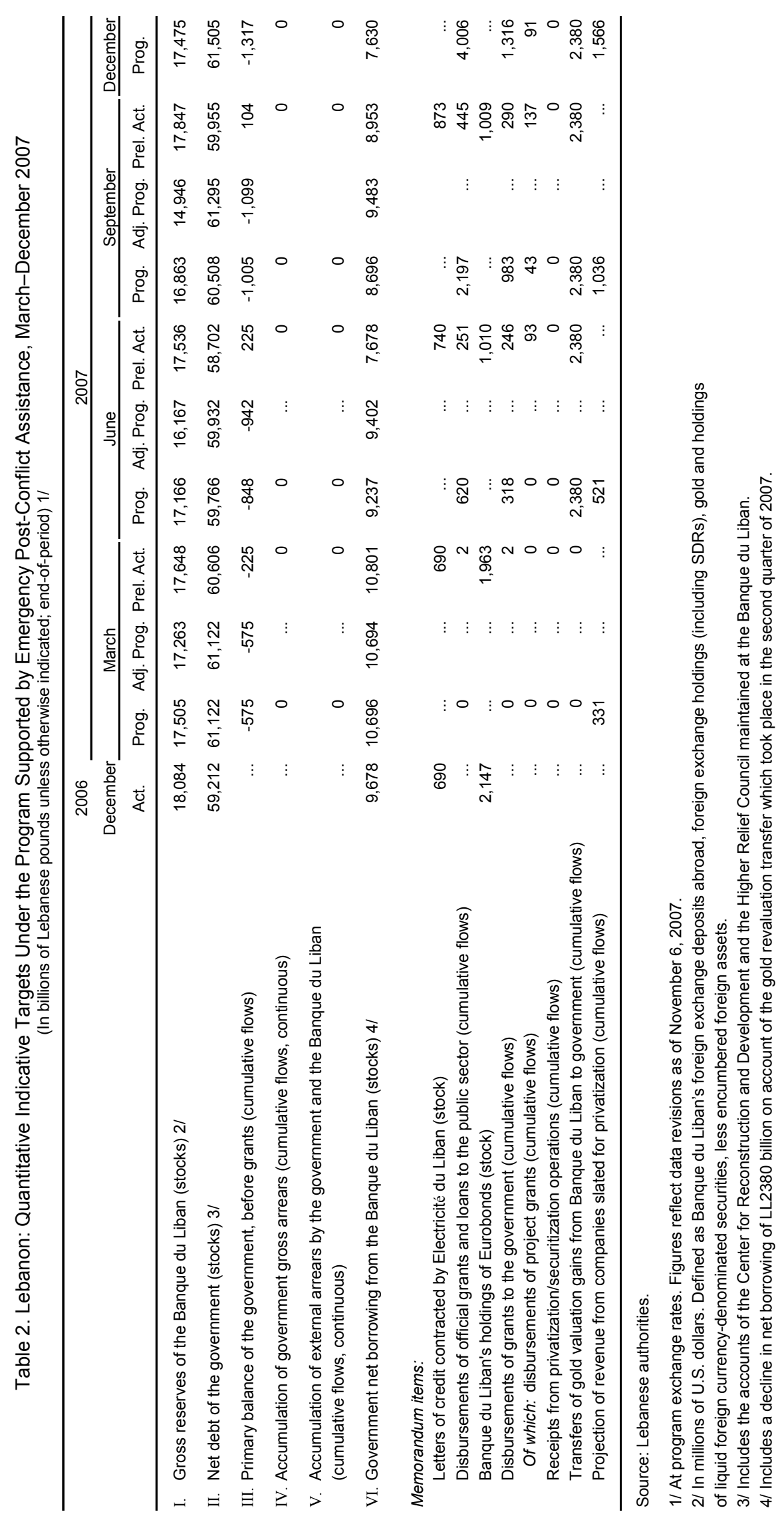


Table 3. Lebanon: Monitorable Actions for the Period March-December 2007

Measure
Fiscal
Submit to parliament a draft 2007 budget law consistent with the
targeted primary balance of the central government, and
including detailed HRC operations and CDR foreign-financed
expenditures. The budget law should not allow budget
carryovers for expenditures for which no third-part liability
already exists, and treasury advances of more than one month
after the fiscal year.
Appoint auditor for NSSF accounts. Auditor to prepare an audit
plan of NSSF for 2001-06.

Issue a Cabinet of Ministers decision setting a specific floor on gasoline excise of LL 300 per liter of gasoline.

\section{Power sector}

Appoint auditor for EdL accounts. Auditor to prepare an audit plan of EdL for 2002-06. Publish 2001 audit report.
Target Date

End-June 2007

End-June 2007

Auditor appointed on June 12, 2007. Contract will be extended to cover 2006 once accounts are closed. Audit plan finalized on August 6.

End-September Not implemented. 2007

End-June 2007

Auditors for 2002-04 appointed on June 1, 2005, and auditors for 2005-06 accounts appointed on March 13, 2007. Audit plan for 2002-06 finalized on July 13. 2001 audit report posted on website on August 27.

End-June 2007

Based on legal opinion from the ministry of justice, the law is not necessary to proceed with the privatization.

End-December 2007

Issue an invitation for expression of interest (EOI) in participating in the process of acquiring the licenses and assets of the two mobile telephone companies (MIC1 and MIC2).
A Request for Application was issued on November 2, 2007. Applications with pre-auction bids are requested for February 1, 2008. 